\title{
Self-Perceived Behavior and Process Evaluation of Bocas Sanas Holanda-Maimón (BSHM, 2020): From the Past to the Future
}

\author{
Selma Y Burrekers ${ }^{1 *}$, Cristina M Doorman-Vasquez ${ }^{1}$, Marjolein JCM Faes-Siebgens ${ }^{1}$, Roselyn A \\ Pascual $^{2}$ and Yvonne AB Buunk-Werkhoven ${ }^{3}$ \\ ${ }^{1}$ Foundation Bocas Sanas Holanda-Maimón, Greonterp, The Netherlands \\ ${ }^{2}$ Foundation Clinicas Odontologicas Sonrisas, Puerto Plata, Dominican Republic
}

${ }^{3}$ SPOH ARTS - International Oral Health Psychology, Amsterdam, The Netherlands

*Corresponding author: Selma Y Burrekers, RDH, Foundation Bocas Sanas Holanda-Maimón, Greonterp, The Netherlands

\section{ARTICLE INFO}

Received: March 17, 2020

Published: April 03, 2020

Citation: Selma Y Burrekers, Cristina M Doorman-Vasquez, Marjolein JCM FaesSiebgens, Roselyn A Pascual, Yvonne AB Buunk-Werkhoven. Self-Perceived Behavior and Process Evaluation of Bocas Sanas Holanda-Maimón (BSHM, 2020): From the Past to the Future. Biomed J Sci \& Tech Res 26(5)-2020. BJSTR. MS.ID.004422.

Keywords: Foundation Bocas Sanas Holanda-Maimón; School-based Oral Health Education and Hygiene program; Oral health education; Promotion of tooth brushing

\section{ABSTRACT}

Objective: To observe, register, report, interpret and evaluate the two weeks schoolbased Oral Health Education and Hygiene program of the Foundation Bocas Sanas Holanda-Maimón (BSHM) in the Dominican Republic in February 2020.

Methods: 225 primary school children around Puerto Plata - a city in a poor region - were screened and treated by the BSHM 2020 team. Moreover, all children of the six schools that were visited, as well as the teachers, received oral health education.

Results: Observational findings show that school-based tooth brushing was appreciated and effective, illustrating the importance of tailored oral health promotion and oral disease-prevention interventions specifically designed for every school context. Interprofessional support was necessary to develop an optimal working alliance among teachers and BSHM-volunteers in the school-based oral health interventions.

Conclusions: $0 n$ the basis of these observations and interpretations, the approach of BSHM will be drawn up and adjusted, especially regarding referrals for further curative dental care of the children and their parents to the CEPREDIMA in Maimón, to the NGO Fundacíon Clinicas Odotologicas Sonrisas or ideally, to the Centro Sanitario, a government agency that provides medical and dental care, and where specialist pediatric dentists work.

\section{Introduction}

In 2008, the Foundation Bocas Sanas Holanda Maimón (BSHM) started a prevention program in the Dominican Republic, with the aim of identifying and improving the oral health of rural school children in the Maimón district, a poor rural area in the Northern province of Puerto Plata. In this region, people live scattered in small villages, where unemployment is high, infrastructure is poor, and schools are sometimes inaccessible during floods. Dental service is not easily accessible to most residents, because of travel distance and the relatively high cost of dental treatments. Also, there is little awareness among parents about the importance of timely preventive and curative care. BSHM provides preventive and curative care with teams of Dutch volunteers who visit the country for two weeks. In the early years during the visits of the BSHMteams only screenings were carried out, and oral health education, including tooth brushing instructions were given to children in community centers. Curative dental treatment was given by Dutch volunteers and on two occasions, by Dominican Republic dentists of the Ministry of Public Health. The emphasis of the Bocas Sanas program is on prevention, through oral health education and tooth brushing at school, according to the method Fit for School. Thanks to this approach the school-based Oral Health Education and Hygiene program BSHM has developed into an example of proven effective prevention [1-2]. 
The program involves an adequate application of evidencebased strategies in oral health promotion and prevention as well as in the treatment of oral diseases [3]. Normally, oral health education is provided mostly within dental practices; children and their parents receive individual attention from the oral care professional. However, the WHO [4] recognizes that primary schools are the most adequate tool for providing information to people who do not visit clinics, because schools are easily accessible. Approaching schools can serve to improve the awareness of the importance of (oral) health and to pay attention to adequate tooth brushing during early childhood. Often it is difficult to determine the effectiveness of a one-time lesson on oral health care [5]. Moreover, there is little evidence that such a tooth brushing intervention actually results in a permanent behavioral change in the children. However, the primary school period is a crucial stage of child development: health-related behavior that is practised routinely is more likely to become habitual, because the success of health education initiatives and programs lies in the ability to understand the differences in psychosocial factors, e.g., knowledge, attitudes, environment, and behavior both at individual and community level [6-8]. Also, oral health interventions need to be embedded within oral health systems that are financially fair for disadvantaged and poor population groups [9].

\section{Methods}

\section{Participants and Procedure}

During two weeks in February 2020, a team of 10 volunteers from the Bocas Sanas Holanda-Maimón foundation, including dentists, dental hygienists, dental assistants, a clinic manager and interpreters visited six schools in the Maimón region. Every day there was participation of one dentist and an oral health educator from the NGO Fundacíon Clinicas Odontologicas Sonrisas. Involvement of the primary schools was agreed, participation of the children and teachers present was on a voluntary basis, they were informed about what participation entailed and free to refuse the check-up and, if called for, curative care [1]. In total, 225 children who participated in the prevention program of BSHM and 220 children from five BSHM-schools were clinically examined. If dental treatment was needed they were treated or referred to the government-run Centro Sanitario, with dentists specialized in treatment for children, to the private clinic CEPREDIMA in Maimón, which collaborated with the foundation BSHM, or to Clinicas Odotologicas Sonrisas in Puerto Plata. Seven teachers from the schools were clinically examined and dental cleaning was performed if necessary. In the sixth school visited, Escuela Paloindio, the five children in this very small school were not screened, but they did receive oral health education. In all schools, the emphasis of the oral health education was on tooth brushing; at least twice a day with a short horizontal tooth brushing method (precursor Bass-method). Use of fluoride toothpaste was promoted and brushing conform the 'inside, outside, upside, backside' brushing order, starting in the lower jaw and continuing the same ordering in the upper jaw (10; Dutch BBBA-method - i.e., brushing order) (translated in Spanish the Adentro, Afuera, Arriba, Atras - system (sistema AAAA).

Using a helicopter view method, the BSHM 2020 program, including the different approaches of the tailored tooth brushing lessons (Table 1), were assessed using semi-systematic participatory observation, i.e., the observer - the last author of this paper-participated in the situation she was observing. In line with an earlier teachers evaluation (1) a meeting in the Escuela Basica La Colorada with the teachers present, the BSHM founder - the second author- and the other co-authors was arranged to gain insight in to what extent the provided oral health education and instructions on 'tooth brushing behavior' were understood, remembered and/ or implemented in this school (Table 1).

Table 1: Oral health education approach and available supplies per school visited.

\begin{tabular}{|c|c|c|c|c|c|}
\hline Escuela & $\begin{array}{l}\text { Oral Health } \\
\text { Education }\end{array}$ & $\begin{array}{l}\text { Classical/ in groups / } \\
\text { individual/role model }\end{array}$ & $\begin{array}{l}\text { Washing Bin With or } \\
\text { Without Water Drainage }\end{array}$ & Own Tooth Brush & $\begin{array}{l}\text { Use of Disclosing + } \\
\text { Fluoride Tooth Paste }\end{array}$ \\
\hline \multicolumn{2}{|c|}{$\begin{array}{c}\text { Escuela Primera Andrés Léon } \\
\text { Cervantes (Maggiolo) }\end{array}$} & In groups + individual check & $\begin{array}{c}\text { Outside a large bin, } \\
\text { including water drainage }\end{array}$ & $\begin{array}{l}\text { Own tooth brush } \\
\text { available in small case }\end{array}$ & Usage of both \\
\hline \multicolumn{2}{|c|}{ Escuela Centro Educativo Los Rielos I } & In groups + individual check & $\begin{array}{l}\text { Outside two small bins, } \\
\text { including water drainage }\end{array}$ & Own tooth brush & Usage of both \\
\hline \multicolumn{2}{|c|}{ Escuela Centro Educativo Los Rielos II } & $\begin{array}{l}\text { In groups + role model + } \\
\text { classical check }\end{array}$ & $\begin{array}{l}\text { No bin and no water } \\
\text { drainage }\end{array}$ & New tooth brushes & No usage of both \\
\hline \multicolumn{2}{|c|}{ Escuela San Marcos Arriba } & In groups + individual check & $\begin{array}{l}\text { Inside in the toilet, a } \\
\text { large bin, including water } \\
\text { drainage }\end{array}$ & New tooth brushes & Usage of both \\
\hline \multicolumn{2}{|c|}{ Escuela Paloindio } & $\begin{array}{l}\text { Classical; only } 5 \text { kids + } \\
\text { individual check }\end{array}$ & $\begin{array}{l}\text { Outside a small bin, no } \\
\text { water drainage }\end{array}$ & New tooth brushes & $\begin{array}{l}\text { Usage of only tooth } \\
\text { paste }\end{array}$ \\
\hline \multicolumn{2}{|c|}{ Escuela El Toro } & In groups + individual check & $\begin{array}{c}\text { Outside a large bin, } \\
\text { including water drainage }\end{array}$ & New toothbrushes & Usage of both \\
\hline \multicolumn{2}{|c|}{ Escuela Basica La Colorada } & $\begin{array}{l}\text { Youngest kids: Classical + in } \\
\text { groups + individual check } \\
\text { Older kids: Classical + role } \\
\text { model and classical check }\end{array}$ & $\begin{array}{l}\text { Outside a large bin, no } \\
\text { water drainage }\end{array}$ & New tooth brushes & No usage of both \\
\hline
\end{tabular}




\section{Results}

Table 1 shows an overview of the approach of oral health education, including supplies at the six schools visited. Depending on the availability of the supplies, the oral health education and tooth brushing instructions were tailored and provided in combinations of a classical, in small groups, individual or by role model approach. The approach featured the introduction of the Spanish 'sistema AAAA' as tooth brushing order instead of advising two minutes tooth brushing per tooth brushing moment. Especially, the role model approach by the participating observer was improvised on site, because there were no washing bins and/or no water, including the individual or classical check on tooth brushing method was an adequate and very well received intervention. In addition, to stimulate parents' oral health awareness and support their supervised tooth brushing and re-brushing, the children were advised to ask their parents or caregivers to check their children's tooth brushing at home.In Table 2 the frequencies of the children's clinical oral health status per school visited by the BSHM team is presented. In Escuela Centro Educativo Los Rielos six children were not treated, because of dental anxiety. In general, some children needed extraction of milk molars, some had arrested caries or other treatments, for example, pulp roofing or a fistel. Two children refused to be screened or treated (Table 2). In Escuela Basica La Colorada tooth brushing was implemented in the daily curriculum schedule for 10 minutes after the lunch. The teachers of this school feel in control of this school-based oral health intervention, because of a good understanding and implementation of this BSHMprogram. All teachers reported to know that preventing caries and encouraging children's oral self-care are the main reasons for tooth brushing at school. Moreover, the school director seemed to be the leader or role model for implementing tooth brushing at all primary schools in the Dominican Republic, to get a tooth brushing installation, including a follow-up of the School-based Oral Health Education and Hygiene program of the Foundation Bocas Sanas Holanda-Maimón (Table 2).

Table 2: Numbers of children's clinical oral health status per school visited.

\begin{tabular}{|c|c|c|c|c|c|c|c|}
\hline Escuela & Screened & Healthy & ART & Sealants & Slice & Calculus & Referral \\
\hline $\begin{array}{l}\text { Escuela Primera Andrés Léon Cervantes } \\
\text { (Maggiolo)* }\end{array}$ & 45 & 11 & 34 & - & - & - & 8 to in Maimón \\
\hline Escuela Centro Educativo Los Rielos* & 71 & 23 & 18 & 6 & 4 & - & $\begin{array}{c}3 \text { to Clinicas Sonrisas in Puerto } \\
\text { Plata }\end{array}$ \\
\hline Escuela San Marcos Arriba* & 48 & 20 & 19 & 9 & 4 & 5 & 9 to both clinics \\
\hline Escuela Paloindio & 0 & - & - & - & - & - & $\begin{array}{l}\text { Clinicas Sonrisas in Puerto } \\
\text { Plata }\end{array}$ \\
\hline Escuela El Toro & 31 & 11 & 16 & 1 & 0 & 3 & 4 to both clinics \\
\hline Escuela Basica La Colorada & 25 & 7 & 7 & 5 & 0 & 1 & 8 to Cepredima in Maimón \\
\hline
\end{tabular}

\section{Discussion}

The aim of this observation report was - after an evaluation in 2015 (1)- to gain insight in the state of art of the school-based Oral Health Education and Hygiene program of the Foundation Bocas Sanas Holanda-Maimón. Observational and oral findings from participation of the oral health educator and five dentists of the NGO Fundacíon Clinicas Odontologicas Sonrisas provided insight into future collaboration opportunities of the BSHM and other oral health organisations, for instance the Ministry of Public Health and La Cruz Roja in Puerto Plata. Again, this report demonstrates that overall the BSHM preventive program was appreciated by the children and by the teachers. In line with previous studies that showed that school-based tooth brushing should include tailored oral health promotion and oral disease-prevention interventions specifically designed for the target population at national level [11]. The long term benefits of this BSHM program and collaboration with other oral health care organisations, including mediumlongitudinal evaluation studies are recommended. This as basis for the BSHM approach to be transferred to the Dominican state and translated into national policy, so as to be formally adopted by the Ministries of Public Health and Education of the Dominican
Republic [12].

\section{Acknowledgments}

The authors would like to thank the team of BSHM 2020: Dominique van den Broek, Nathalie van der Zandt, Nico and Minke Moonen, Seron Wartanian, Jolanda Gortzak, Safija Incesulu, Agatha Rijpma-Huitema, Madelon Knebel, and Frans Doorman as well as the dentists of NGO Fundacíon Clinicas Odontologicas Sonrisas, Michael Gim Simons Sandoval as the assistant of La Cruz Roja in Puerto Plata, the schoolchildren, teachers and others involved. In addition, special thanks to Frans Doorman and Abraham Buunk for revising the draft manuscript critically. For many years, the tooth brushes and fluoride tooth pastes for the BSHM program were kindly supported by Colgate and various oral health sponsors in the Netherlands.

\section{Conflict of Interest}

The authors declare that they have no conflict of interest.

\section{References}

1. Buunk-Werkhoven YAB, Burrekers SY(2019) Effects and benefits of a program to promote tooth brushing among 12-year-old school children in the Dominican Republic. Adv Dent \& Oral Health10:555799. 
2. Buunk-Werkhoven YAB, Burrekers SY, Jongboer A, Quant DF (2011)Determinants of oral hygiene behavior in the Dominican Republic. Int Dent J 61:328-333.

3. (2020) World Health Organization. The objectives of the WHO Global Oral Health Programme (ORH).

4. (2020) World Health Organization. Dominican Republic.

5. Buunk-Werkhoven YAB, Burrekers SY (2017) Oral health awareness, promotion of home oral self-care, and professional oral health care among young mothers and their babies: a pilot project. Oral Health and Care2:1-4.

6. Adair P, Ashcroft A (2007) Theory-based approaches to the planning and evaluation of oral health education programmes. In: Pine $\mathrm{C}$, Harris R (Eds.), Community Oral Health. $2^{\text {nd }}$ (edn.). United Kingdom: Quintessence pp. 307-331.

7. Buunk-Werkhoven YAB, Dijkstra A, Van der Schans CP O (2011) Determinants of oral hygiene behavior: A study based on the theory of planned behavior. Community Dent Oral Epidemiol 39: 250-259.

ISSN: 2574-1241

DOI: $10.26717 /$ BJSTR.2020.26.004422

Selma Y Burrekers. Biomed J Sci \& Tech Res

(C) This work is licensed under Creative

Submission Link: https://biomedres.us/submit-manuscript.php
8. Brein DJ, Fleenor TJ, Kim SW, Krupat E (2016) Using the theory of planned behavior to identify predictors of oral hygiene: a collection of unique behaviors. J Periodontol 87(3): 312-319.

9. Petersen PE (2009) Global Policy for Improvement of Oral Health in the $21^{\text {st }}$ Century-Implications to Oral Health Research of World Health Assembly 2007, World Health Organization. Community Dent Oral Epidemiol 37(1): 1-8.

10. Buunk-Werkhoven YAB (2020) Did the parents/carers manage to support their children in the past year in their intentions to brush their teeth conform the Dutch 'BBBA-method' more consciously? Dutch Newsletter.

11. Hawkins R, Kreuter M, Resnicow K, Fishbein M, Dijkstra A (2008)Understanding tailoring in communicating about health. Health Edu Res 23(3): 454-466.

12. Katsman E (2007) Report on the activities carried out by 'Sonrisas' to promote oral health: the experience of a Canadian dental hygienist in the Dominican Republic. Int J Dent Hygiene 5(3): 139-144.

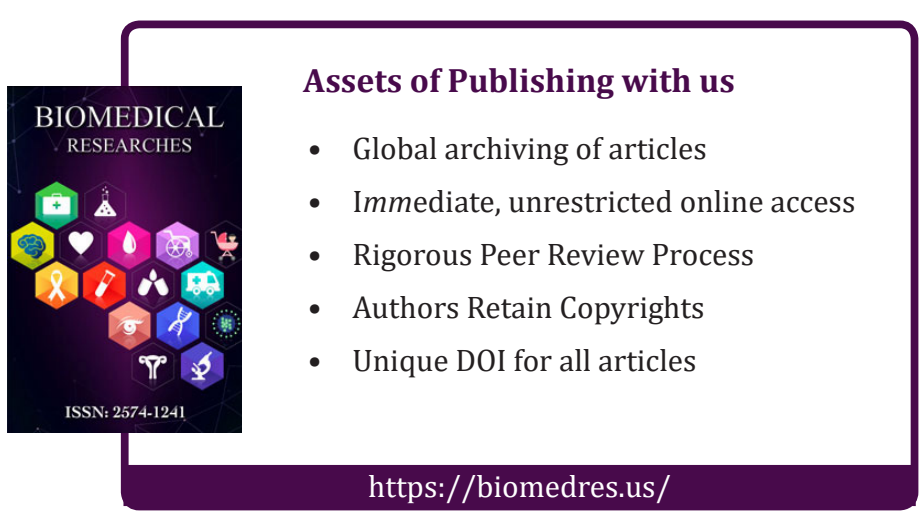

